\title{
KUALITAS SPERMA EJAKULAT PEJANTAN AYAM KUKUAK BALENGGEK PADA PENGANDANGAN TUNGGAL TERISOLASI (Ejaculated Sperm Quality of Isolated Single Caging of Balenggek Chickens)
}

\author{
Ramadhan Sumarmin $^{1}$, Elsa Yuniarti ${ }^{2}$ dan Abdul Razak ${ }^{3}$ \\ ${ }^{1}$ Laboratorium Zoologi, ${ }^{2}$ Laboratorium Fisiologi Hewan, ${ }^{3}$ Laboratorium Ekologi \\ Jurusan Biologi, FMIPA Universitas Negeri Padang, Sumatera Barat \\ ramadhan_unp@yahoo.com, elsayuniarti230682@yahoo.com,ar710322@gmail.com
}

\begin{abstract}
The Balenggek chicken is a long crower type fowl. This fowl have isolated and caging in single cage for years to result the long crower sound.This study was carried out to identify the influence of fed to the ejaculate sperm quality of balenggek chickens. First, the sperm were collected from isolated caging of Balenggek fowl more or less than three years and un-isolated caging of Balenggek fowl as control group. Second, the sperm were collected from isolated caging of Balenggek fowl more or less than three years and unisolated caging of Balenggek fowl as control group, after treated by 124 ComFed for three months. The sperm were collected by massages methods and analyze with counting chamber of Improve Neubauer. Slides of sperm were stained by Eosin. Variables observed were sperm ejaculated, colours, and sperm consistency. The results shows that the sperm quality of Balenggek fowl increased (from 2.5 billion sperm $/ \mathrm{ml}$ to 3.5 billion sperm $/ \mathrm{ml}$ ) significantly higher $(\mathrm{p}<0.05)$ in isolated caging fowl with reschedule feeding. Sperm color and its consistency were increased from + (c quality) to ++ (b quality). It can conclude that single caging could decreased the ejaculated sperm of Balengggek chickens quality and it. could reveal increased after it treated by 124 ConFed.
\end{abstract}

Key Words: Balenggek chickens, 124 ConFed, sperm quality, isolated

\section{PENDAHULUAN}

Indonesia merupakan salah satu negara yang memiliki keanekaragaman hayati terbesar setelah negara Brazil. Sebagai salah satu negara Megabiodiversity haruslah menjadi perhatian bagi pemerintah khususnya dan masyarakat pada umumnya untuk dapat menjaga kelestariannya. Hampir 85\% spesies yang ada di dunia terdapat di Indonesia termasuk keanekaragaman hayati burung-burung atau Avifauna, baik burung-burung migran ataupun burungburung asli Indonesia.
Namun keanekaragaman hayati ini mulai terancam dengan adanya pembalakan liar terhadap hutan tropis Indonesia sehingga terjadi kerusakan habitat tempat tinggal berbagai jenis hewan. Kerusakan habitat hewan ini diperparah lagi dengan adanya perladangan liar dan pembakaran hutan untuk aktifitas perladangan. Kerusakan habitat hutan ini lebih jauh akan mengancam keberadaan satwa langka yang dilindungi (endangered species) yang terdapat di hutan-hutan Indonesia. 
E-ISSN : 2549-7464, P-ISSN : 1411-3724

Unggas yang dikenal saat ini secara ilmiah adalah hewan yang termasuk dalam Kelas Aves yang memiliki ciri-ciri utama memiliki bulu (feather umumnya plumae dan filloplumae), paruh (beak), sisik pada kaki dan glandula uropigealis (Nalbandov, 1995). Berdasarkan pada perkembangan awal setelah menetas maka Aves terbagi atas dua kategori yaitu yang bersifat precocial yaitu mampu mencari makan sendiri dan yang bersifat altricial yaitu anakan burung yang menetas dengan kondisi masih gundul dan mata yang masih tertutup sehingga bergantung pakan pada induk dan makan dengan cara dilolohkan (Mc. Kinnon, 2010). Berdasarkan habitat yang dihuninya Aves terbagi menjadi unggas yang terestrial atau unggas air (waterfowl) perairan tawar dan laut (Strange, 2012).

Berdasarkan tipenya ada dua jenis suara pada bangsa unggas yaitu call (suara panggilan) dan song (suara nyanyian). Tipe suara call digunakan untuk berkomunikasi antar sesama jenis, sebagai isyarat adanya musuh atau predator, saat terkejut dan saat menemukan makanan. Tipe suara song merupakan tipe suara sebagai pernyataan wilayah kekuasaan (territorial declare) dan sebagai atraksi untuk memikat betina yang akan dikawini (Strange, 2012). Tipe suara call terdapat pada jantan dan betina sedangkan tipe suara song hanya terdapat pada jantan saja (Rusfidra, 2007)

Ayam kukuak balenggek merupakan jenis ayam yang eksotik khas Sumatera Barat khususnya Solok. Keindahan lantunan kukuak (kokok) yang panjang dan bertingkat adalah ciri khas suara kokok ayam jenis ini. Populasi ayam ini sangat terbatas sedangkan potensi pengembangannya cukup terbuka. Berbagai cara dan teknologi telah dicoba selama ini untuk meningkatkan populasinya.

Pada penelitian ini akan dilakukan pengamatan pada kualitas sperma ayam kokok Balenggek yang berasal dari Solok sebelum dan sesedah perbaikan pakan. Diduga telah terjadi penurunan kualitas sperma ayam kokok Balenggek akibat isolasi pemeliharaan pejantan dengan suara merdu ini pada kandang hias tipe tunggal. Pada umumnya pemilik hewan ini juga keberatan jika ayamnya dilepas bebas bersama ayam lain karena takut menurunkan kualitas suaranya.

\section{METODE PENELITIAN Materi Penelitian}

Ayam jantan kukuak balenggek yang digunakan pada penelitian ini adalah sebanyak 10 ekor berumur antara 4-5 tahun, dengan level kukuak tiga atau lebih. Pada tahap awal dilakukan penentuan kualitas sperma ejakulat, saat pertama kali ayam jantan kukuak balenggek tersebut di inventarisir dari hasil survey. Setelah dilakukan koleksi sperma awal dan penentuan kualitasnya, kemudian pada seluruh AKB diberi perbaikan pola pakan dengan ComFed dan sejalan dengan pemeriksaan kualitas sperma sebulan sekali selama tiga bulan berurutan.

\section{Tata Kerja Penelitian}

Pada tahap awal penelitian dilakukan pembiasaan pada ayam jantan AKB sampel untuk dapat ejakulasi tanpa kopulasi. Ejakulasi pada ayam jantan dirangsang dengan cara melakukan masase pada bagian ischio-pubis. Kontraksi pada otot yang menyebabkan bulu-bulu ornamen posterior berdiri adalah sinyal akan terjadinya ejakulasi (Obidi et al, 2016). Segera tanda tersebut muncul Sperm testube collection ditempatkan tepat di lubang pelepasan 
E-ISSN : 2549-7464, P-ISSN : 1411-3724

kloaka untuk menampung sperma ejakulatnya. Hal ini dilakukan sebanyak tiga kali pada masing-masing pejantan AKB. Setelah ayam terlatih untuk ejakulasi dengan rangsangan masase maka preparasi sperma dapat dilakukan.

Ejakulat sperma ayam hasil rangsang masase ditampung dalam gelas penampung sperma yang khusus untuk menampung sperma ayam (Sperm testube collection). Pada setiap kali penampungan sperma dicatat volume ejakulat (ml), konsistensi (kekentalan), dan warna. Setelah itu dilakukan perhitungan jumlah sperma/ejakulat dengan menggunakan counting chamber Improve Neubauer (Kiernan, 1990; Junquera dan Corneiro, 1991; Winarto, 2013).

Data hasil pengamatan berupa data parametrik, jumlah sperma per ml di awal dan diakhir pengamatan dibandingkan dan diuji dengan uji tStudent, sedangkan data nonparametrik berupa skor kekentalan atau konsistensi dan warna sperma dideskripsikan dan dibandingkan antara data awal dan akhir (Steel dan Torrie, 1995).

\section{HASIL DAN PEMBAHASAN}

Pada awal penelitian dilakukan penentuan profil reproduksi pejantan AKB dengan mengukur kualitas sperma AKB untuk mengetahui kemampuan reproduksinya atau tingkat kesuburan berdasarkan volume dan jumlah sperma. Hasil pengamatan terhadap parameter ejakulat ditemukan bahwa jumlah sperma ejakulat pada AKB di awal pengamatan $(\mathrm{AKBw})$ lebih rendah dibandingkan dengan jumlah sperma ejakulat ayam pejantan $\mathrm{AKB}$ setelah diberi perlakuan pakan ComFed (AKBp). Begitupun dengan kriteria lainnya seperti jumlah konsistensi, dan warna sperma (Tabel 1) memperlihatkan peningkatan kualitas sperma pada AKB setelah perbaikan pakan.

Tabel 1. Perbandingan awal kualitas sperma ayam kokok Balenggek (AKBw) dan setelah perbaikan pakan (AKBp)

\begin{tabular}{|c|c|c|c|c|c|c|}
\hline \multirow[b]{2}{*}{ No } & \multirow[b]{2}{*}{ Sumber } & \multirow[b]{2}{*}{$\begin{array}{c}\text { Rerata } \\
\text { Berat } \\
\text { Badan } \\
(\mathrm{kg})\end{array}$} & \multicolumn{4}{|c|}{ Keadaan Sperma } \\
\hline & & & $\begin{array}{l}\text { Ejakul } \\
\text { at }(\mathrm{ml})\end{array}$ & $\begin{array}{c}\text { Jumlah } \\
\text { sperma } \\
\text { (milyar)/ml }\end{array}$ & $\begin{array}{c}\text { Konsis } \\
\text { tensi }\end{array}$ & $\mathrm{Bau}$ \\
\hline 1 & $\mathrm{AKBw}$ & 1,8 & 0,3 & $2,5^{\mathrm{a}}$ & + & + \\
\hline 2 & $\mathrm{AKBp}$ & 1,9 & 0,4 & $3,5^{\mathrm{b}}$ & ++ & ++ \\
\hline
\end{tabular}

Keterangan: Angka pada kolom sama yang diikuti huruf berbeda, berbeda nyata $\mathrm{p}<0,05$ pada uji t-Student

Rendahnya kualitas sperma pejantan $\mathrm{AKB}$ terisolasi dengan pakan hanya mengandalkan pada beras saja menyebabkan perlu dilakukan penyempurnaan pakan untuk pemulihan kualitas sperma. Setelah pemberian pakan ComFed kualitas sperma menjadi lebih baik meskipun kualitas konsistensi dan bau hanya setingkat lebih tinggi dibandingkan dengan kualitas sperma AKB sebelum treatment. Pada umumnya pejantan AKB terisolasi yang didapatkan dikandangkan secara terpisah, terisolasi dari koloni ayam lainnya dan ditempatkan pada kandang tunggal. Faktor ketiadaan pertemuan antara pejantan AKB dan betinanya ini kemungkinan juga mengakibatkan sedikitnya jumlah sperma ejakulat. Libido yang relatif rendah dalam jangka waktu yang lama (3-4 tahun) akan mengakibatkan produksi sperma juga akan berkurang. Tidak adanya rangsangan atau stimulus keberadaan betina disekitar pejantan AKB menyebabkan pejantan ini lebih sering berkokok untuk menggunakan energi yang ada, sehingga semakin lama suara kokoknyalah yang akan semakin merdu (Piccione dan Caola, 2012). 
E-ISSN : 2549-7464, P-ISSN : 1411-3724

Kemungkinan lainnya adalah, semakin lama terisolasi akan semakin menurunkan kualitas sperma ayam pejantan AKB dan kemampuan kawinnya. Pada uji kawin yang dilakukan ternyata kemampuan pejantan AKB untuk mounting (menaiki) betina sering salah penampatan. Posisi pejantan AKB lebih sering bersisian dengan betinanya sehingga perkawinan tidak terjadi.

Menurut Penfold et al (2016) dan Brillard (2015) kecenderungan frekuensi pertemuan antara ayam pejantan dan betina yang lebih tinggi akan memacu libido ayam jantan dan merangsang terjadinya pengaktifan proses spermatogenesis lebih kontinu. Apalagi jika hal itu diikuti dengan perkawinan antara jantan dan betina tersebut, maka proses spermatogenesis akan berjalan secara intensif dan konstan. Sebaliknya pada ayam jantan yang tidak pernah kawin maka proses spermatogenesis akan terhambat.

Kualitas dan kuantitas beberapa ekor pejantan tetap tidak berubah setelah enam minggu perbaikan pola pakan (Tabel 1). Meskipun pola pakan telah diperbaiki tetapi tanpa disertai mempertemukan pejantan dan betina maka hasilnya akan tetap kualitas sperma AKB terisolasi dipertahankan rendah. Perkawinan akan menyebabkan sperma yang telah dihasilkan dikeluarkan dan diproduksi sperma yang baru. Tanpa perkawinan maka sperma yang telah dihasilkan akan tetap menghuni spermateca (kantong sperma) dan mencegah terbentuknya sperma yang baru. Pada bangsa Aves umumnya tidak terjadi kompensasi pengeluaran sperma secara masturbasi sebagaimana halnya pada Mamalia (King et al, 2014 dan Gilbert, 2014).

Penurunan kualitas sperma AKB terisolasi diduga juga berkaitan erat dengan rerata berat testis AKB terisolasi yang berada di bawah rerata berat testis AKB yang dipelihara bersama ayam betina (Tabel 2). Aktifitas spermatogenesis seca kontinu akan dirangsang atau dipacu dengan adanya aktifitas perkawinan. Selain itu kemampuan kawin pada ayam jantan akan semakin baik jika tersedia banyak betina. Satu ekor ayam jantan mampu melayani 10-12 ekor ayam betina (Obidi et al, 2016). Hal ini juga memperlihatkan bahwa aktifitas spermatogenesis pada testis AKB terisolasi lebih sedikit dibandingkan aktifitas spermatogenesis pada testis AKB bebas.

Tabel 2. Berat rerata testis AKB terisolasi dan AKB bebas, sebelum dan sesudah perbaikan pakan.

\begin{tabular}{|c|c|c|}
\hline \multirow{2}{*}{ Ayam } & \multicolumn{2}{|c|}{$\begin{array}{c}\text { Rerata berat sepasang testis } \\
\text { (gram) }\end{array}$} \\
\cline { 2 - 3 } & Awal & $\begin{array}{c}\text { Setelah } \\
\text { perbaikan pakan }\end{array}$ \\
\hline $\mathrm{AKBi}$ & $9,2 \pm 0,35$ & $9,5 \pm 0,30$ \\
\hline $\mathrm{AKBb}$ & $18,8 \pm$ & $21,5 \pm 0,42^{*}$ \\
& $0,29 *$ & \\
\hline
\end{tabular}

Keterangan: Angka pada kolom yang sama diikuti * berbeda nyata pada $\mathrm{p}<0,05$

Perbaikan pola pakan selama enam minggu tidak mampu meningkatkan aktifitas spermatogenesis pada AKB terisolasi. Berat rerata testis sebelum dan sesudah perbaikan pakan tidak memperlihatkan kenaikan yang signifikan. Kemungkinan faktor kehadiran betina di sekitar pejantanlah yang dapat meningkatkan aktifitas spermatogenesis karena dapat meningkatkan keinginan kawin pada ayam jantan.

\section{KESIMPULAN}

Berdasarkan hasil dan pembahasan pada penelitian ini dapat disimpulkan: 
E-ISSN : 2549-7464, P-ISSN : 1411-3724

1. Kualitas sperma ayam jantan AKB menmeningkat setelah dilakukan perbaikan pola pakan.

2. Peningkatan kualitas sperma ayam AKB tidak diikuti dengan peningkatan rerata berat testis.

\section{SARAN}

Perlu dilakukan penelitian tentang pengaruh kehadiran ayam betina dan lama perbaikan pola pakan terhadap pemulihan aktifitas spermatogenesis pada ayam jantan AKB.

\section{UCAPAN TERIMAKASIH}

Penulis mengucapkan terimakasih pada Rektor dan Kepala Lembaga Penelitian Universitas Negeri Padang atas pembiayaan penelitian ini melalui Universitas Negeri Padang pada Hibah Penelitian Strategi Nasional.

\section{DAFTAR PUSTAKA}

Brillard JP. 2015. Practical aspects of fertility in poultry. Worlds Poult. Sci. J. 59: 441-446

Gilbert F. Scott. 2014. Developmental Biology. $4^{\text {th }}$ edition. Sinauer Association, Inc. Sunderland, Massachusetts. P. 803-805.

Junqueira LC, and Corneiro J. 1991. Histologi Dasar. Edisi 2. Penterjemah Adji Dharma. EGC.Jakarta.

Kiernan JA. 1990. Histological \& Histochemical Methods. $2^{\text {nd }}$ Edition. Pergamon Press. Oxford.
King LM, Brillard JP, Garret WM, Bakst MR, and Donoghue AM. 2014. Segregation of spermatozoa within sperm storage tubules of fowl and turkey hens. Reprod. 123: 79-86

Mc Fadden CH, and Keeton WT. 1995. Biology an exploration of life. W.W. Norton \& Company. New York. London. Pp 678-686.

Mc. Kinnon, J., Philips K., and Van Halen B. 2010. Burung-burung di Sumatera, Jawa, Bali, dan Kalimantan. Puslitbang Biologi, LIPI. Indonesia.

Nalbandov AV. 1995. Reproductive Physiology of Mamals and Birds. $3^{\text {rd }}$ Edition. WH Freeman \& Company. San Fransisco.

Obidi JA, Onyeanusi BI, Ayo JO, Rekwot PI, and Abdullahi SJ. 2016. Effect of timing of artificial insemination on fertility and hatchability of Shikabrown breeder hens. Poult. Sci. 7(12): 1224-1226.

Penfold LM, Wildt DE, Herzog TL, Lynch W, Ware L, Derrickson SE, and Monfort SL. 2016. Seasonal pattern of $\mathrm{LH}$, testosterone and semen quality in Northern Pintail duck. Reprod. Fertility and Dev. 12: 229-235.

Piccione, G and Caola G. 2012. Biologycal rhythm in Livestock. $J$. Vet. Sci. 3: 145-157.

Rusfidra A. 2007. Kajian bioakustik pada ayam kokok Balenggek "ayam local penyanyi" dari Sumatera Barat. http://rusfidra.multiply.com. Diunduh januari 2008 
Steel RGD and Torrie JH. 1995. Prinsip

Dan Prosedur Statistik.

Penterjemah Soemantri. Gramedia. Jakarta.

Strange, Morten. 2012. Birds of Indonesia. Second Editions. Tuttle Publishing. Singapore.

Winarto A. 2003. Prosedur pendeteksian bahan aktif dengan metode baku/konvensional. dalam Pemanfaatan Teknik Kultur Jaringan dan Histokimia. Kerjasama Proyek Peningkatan SDM DIRJEN DIKTI DEPDIKNAS dengan Bagian Anatomi FKH IPB. Bogor. 